\title{
The Identity of Gurabunga Traditional Architecture and its Response to Sustainability
}

\author{
Mustamin Rahim $^{1 *}$, Arham Munir ${ }^{1}$, and Darmawijaya ${ }^{2}$ \\ ${ }^{1}$ Department of Architecture, Faculty of Engineering, Khairun University, Ternate-Indonesia \\ ${ }^{2}$ Department of History, Faculty of Cultural Studies, Khairun University, Ternate-Indonesia
}

\begin{abstract}
Traditional architecture is an essential part of human civilization. The house concept in Indonesia is very diverse and has different characteristics according to the culture and environmental conditions of the region. This study aims to evaluate the identity of Gurabunga traditional house in Tidore Island and analyze the positive features that can be developed in sustainable development through literature studies and field observations. The study results show that Gurabunga traditional houses are traditional sacred and magical buildings with a philosophy of the human body anatomy in a standing position; roof (head), walls and rooms (body), foundation (foot). It is very friendly to the environment and sustainability based on local wisdom, with passive design techniques using natural materials from the surrounding environment. These research findings will increase insight into the concept of sustainable building design in the future.
\end{abstract}

Keywords: Traditional architecture, Human civilization, Sustainable development

\section{Introduction}

Environmental challenges continue to increase due to global warming, so that the discussion of sustainable development has become an exciting topic lately. In architecture, the development of modern buildings with their various sophistication and splendor contributes to an increase in global energy consumption, where the consumption of non-renewable energy is one of the causes of an increase in $\mathrm{CO}_{2}$ in the atmosphere. According to [1], contemporary buildings are associated with various characteristics that deplete the environment, such as carbon footprint, uncontrolled energy consumption, wasteful use of resources, and increased pollution. Based on this condition, so many researchers are interested in studying the values of sustainability in traditional architecture; the ecological friendliness of traditional architecture thus continues to be positioned as a storehouse of knowledge and positive values that can be utilized in contemporary design to develop a more sustainable built environment.

Indonesia is an archipelagic country that has various kinds of customs, cultures, and natural resources. The richness of culture and natural wealth in Indonesia is the identity of the life of the Indonesian nation. This cultural wealth makes Indonesia have a variety of traditional architecture passed down from generation to generation. Indonesia has more than three hundred tribes with various customs. Each tribe has a unique traditional house, so that Indonesia has hundreds of diverse traditional houses [2]. Traditional architecture is passed down from generation to generation continuously from one generation to the next. Traditional architecture is physical culture closely related to people's personalities. Socio-cultural factors and environmental conditions strongly influence physical expressions, so sociocultural and environmental differences affect architectural characteristics [3].

North Maluku is an archipelago prone to earthquakes, inhabited by various tribes, and has several traditional houses that still exist today, one of which is the traditional house Folajikusesurabi in Gurabunga Tidore. Gurabunga is a traditional village located on Mount Kie Matubu with a height of 1,730 above sea level. The traditional house of Folajikusesurabi (Folajiku) was built with simple materials from the surrounding environment but can survive from the hegemony of modern building developments so that it is interesting to study further as a lesson in the future. Many tribes in Indonesia have various traditional houses and settlements with a unique history, so the traditional architecture of Indonesia is an exciting and essential study object for examining the values of local wisdom that are beneficial to modern building design [4]. Therefore, this study will identify the characteristics of Gurabunga traditional architecture and examine the positive values that can be transferred into sustainable contemporary buildings design.

\footnotetext{
* Corresponding author : mustamin_rahim@yahoo.co.id
} 


\section{Methodology}

This study used a qualitative method that emphasizes identifying the characteristics of Gurabunga traditional architecture and its response to the environment and sustainability through literature and field studies. A literature study was conducted by searching online and offline literature related to the traditional architecture of Gurabunga, especially those related to history and philosophy buildings. Field studies were carried out by direct observation to the study object to document site conditions, orientation and shape of buildings, construction systems, and building materials. Also, direct interviews were conducted with the head of the Gurabunga village and occupants' of a traditional house to find out things related to culture, space functions, and activities in the traditional house. The study area is located in eastern Indonesia on Tidore Island (Fig. 1).

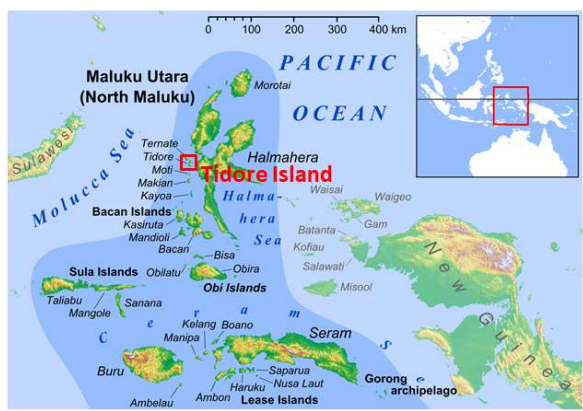

Fig. 1. Study area in Tidore Island, Indonesia.

\section{Result and Discussion}

\subsection{Building Philosophy}

Folajiku traditional house is essential and sacred for the Tidore people because it is the center of community activities, especially those related to customs such as deliberation to open new gardens, deliberation for harvesting, settlement of customary disputes, including the inauguration ceremony of the Sultan of Tidore. In addition, the Folajiku house functions as a place for carrying out various magical traditions such as rituals and offering to ancestors, therapy, and a place to pray or spiritual activities. Therefore, the construction process of Folijiku houses must follow customary rules that have been regulated and maintained for generations [5].

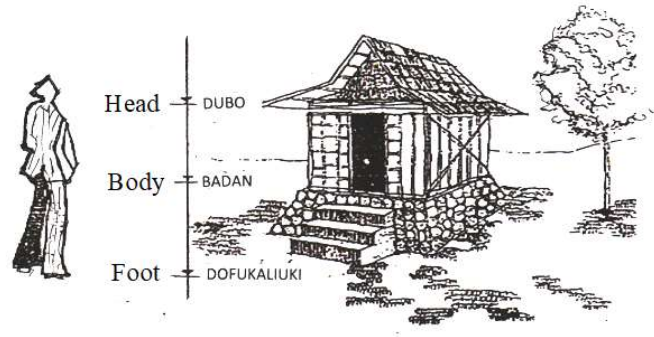

Fig. 2. Building Philosophy of Folajiku.

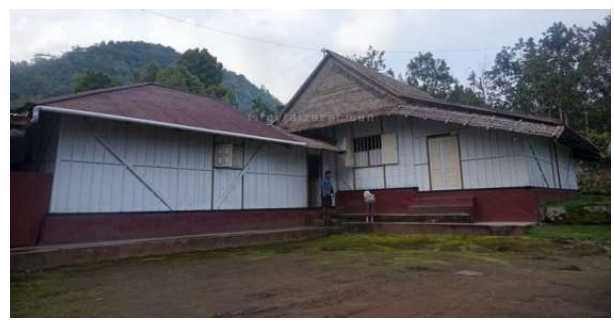

Fig. 3. Gurabungan Traditional House (Folajiku).

Figures 2 and 3 show the philosophy and typology of Folajiku, which symbolizes the human body anatomy; roof (head), walls and room (body), foundation (foot). The meaning of this philosophy is that the building must be strong, stable, and able to withstand any conditions like humans, and psychologically to create a "harmonious relationship" between the occupants and their residence. According to [6] that in any living condition, the occupant's behavior is not only influenced by the spatial and environmental aspects, but also the perceptions, feelings, and needs of the occupants, as well as the user's socio-cultural context. According to Pallasmaa [7], The house is not just an architectural design but has an aesthetic value and must consider physical, psychological, and socio-cultural phenomena. In building design, one must consider physical form, mental image, and psychological aspects [8].

\subsection{Building Construction}

\subsubsection{Foundation}

The house foundation symbolizes human feet. It means that the foundation is the footing of the house building, so it must be strong, balanced, and stable, and able to withstand various situations like human feet. The foundation construction process begins with excavating the soil to install the river stone foundation structure. The river stones are arranged according to floor plan layout, with the height of the stone arrangement varying around $20-80 \mathrm{~cm}$ according to the condition of the soil contour. The building sloef (gaomadini) uses wholelarge bamboo. At the four corners of the building, there are bamboo/wood poles (ngasu) as the main structure supporting the roof truss, backed with flat stone (sogoloi) as compressive load reinforcement. The crosses of each gaomadani angle are reinforced with a clamping system (gapa) (Fig.4). In subsequent developments, the material of foundations has been replaced with stone materials with a mixture of sand and cement. The floor of the building uses clay material and still survives to this day. The use of soil material gives a natural impression and means that the soil is the source of life and the footing of living things. Moreover, the use of natural land surface can improve thermal comfort [8]. According to Balaguer et al. [9] that construction built with soil materials offers a global solution to achieve indoor comfort. 


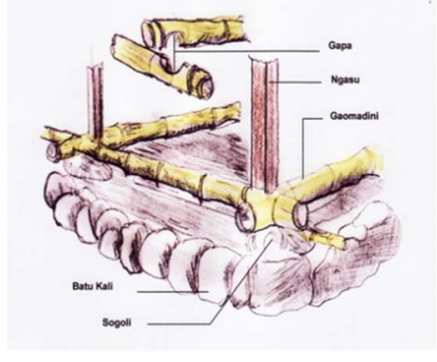

Fig. 4. Illustration of Foundation Construction.

\subsubsection{Wall of Building}

Figure 5 shows a house wall construction system, which uses bamboo materials of various sizes. Bamboo with large size is used as a "tie beam" (Gaomadini). The wall material uses Teto or bamboo sheets, with a $20-30 \mathrm{~cm}$ width. Teto material is installed vertically and clamped two bamboo splits (Jaha) from the outside and inside of the wall; the distance between the Jaha is about 30-60 $\mathrm{cm}$. Teto wall material is arranged in 2 layers for protection from extreme weather conditions and occupant safety. Teto is reinforced with medium bamboo rods called Jaro; the distance between the Jaro is about $30-60 \mathrm{~cm}$. In addition, for withstanding the shift of the wall material, it is reinforced with transverse bamboo (Tuja), which functions to stabilize the position of the bamboo wall, especially during an earthquake, and is reinforced with fiber ties (Gamutu) so that it is not quickly released when there is an earthquake vibration. It shows that principles of earthquake protection have been carried out in the past. It portrays that even though traditional communities' economic conditions and resources are minimal, they still try to adapt their homes to extreme environmental conditions and protect against earthquake disasters.

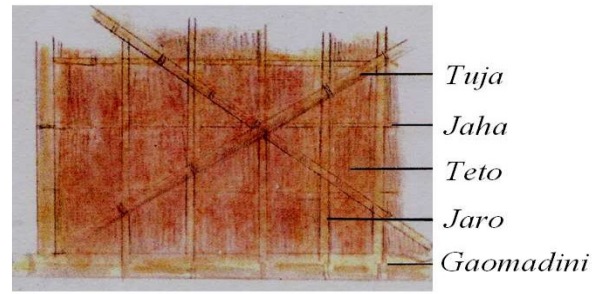

Fig. 5. Illustration of Wall Construction.

\subsubsection{Roof of Building}

The roof of a building is like a human head, which is the highest and most important part of the structure of the human body. A roof construction system is known as a scissor model construction system (Gaokaluguti). The material of roof uses natural materials from the surrounding environment (Fig. 6). The roof frame is the whole bamboo material, tied with Gamutu rope, and roof material from sago leaves. This natural material helps reduce heat transfer from the outside building. Traditional materials can improve indoor thermal comfort [10]. According to Manurung [11], using natural materials from the surrounding environment without chemical preservation is one example of sustainable access in the building construction process.

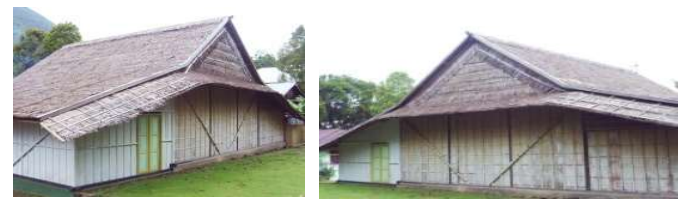

Fig. 6. The roof of Folajiku Traditional House.

\subsubsection{Space Pattern}

The traditional house of Folajiku is used for traditional and magical activities (occult powers), consisting of the main building and kitchen. The main building functions as a residence for traditional stakeholders as well as a place for formal (cultural activities) and non-formal activities, consisting of 4 rooms in the main building (Fig. 7), namely (1) Sarabi (Terrace); this room is a public space and is used by traditional stakeholders to receive non-formal guests. (2) Konora room (living room); this room is semi-private space with the position between the foyer and bedroom. Konora room is used to receive guests of honor and a place for the traditional ceremony of the Salai Jin (ritual ceremony) and a place for deliberation. (3) Jiko room or bedroom. (4) Fuji room (ritual and magic rooms), this room is a sacred and private space, only certain people can enter this room, which functions as a place for rituals and spiritual for traditional holders and also as a place for storing equipment of traditional ceremony and it is the identity of Gurabunga traditional house. It shows that cultural values and local wisdom are very strongly in the Gurabunga traditional house. According to [12], ethnicity, art, architecture, and culture are interrelated in daily activities and become the identity of settlements.

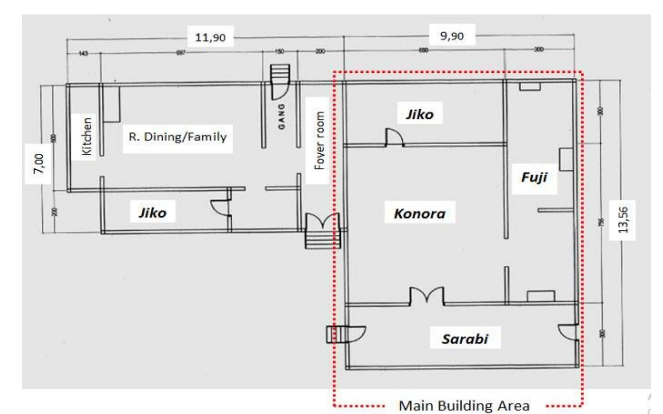

Fig. 7. The layout of Folajiku Traditional House.

\subsubsection{Sustainability}

Traditional architecture tends to pay attention to the needs of residents in terms of indoor comfort [13]. The main factors that influence traditional architecture include local environmental conditions, materials, construction techniques, and the needs of building occupants [14]. Vernacular architecture exemplifies the highest form of sustainable building, as it usually uses environmentally friendly materials and technologies [15]. The values of local wisdom are very strongly in the 
traditional architecture of Folajiku with a spiritualhuman-nature harmony approach [16].

The Gurabunga house uses natural materials from the surrounding environment; bamboo material is used as building frames and walls, foundations of river stone, clay floors, and roofs of sago leaves (Fig. 8). In addition, the traditional Gurabunga house takes advantage of solar energy, wind pressure, and the thermal properties of the building envelope by properly integrating them into the house design to improve indoor thermal comfort. The Gurabunga settlement is located on mount Kie Matubu with cool environmental conditions and abundant solar energy strongly supporting the application of natural ventilation. Natural ventilation is an important and efficient passive technique to reduce building cooling energy needs and improve indoor air quality [17].

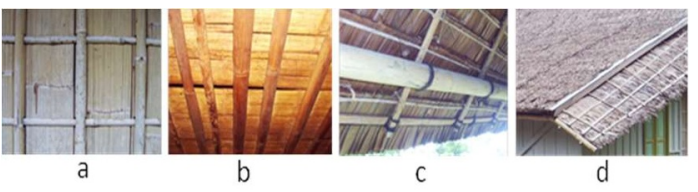

Fig. 8. Bamboo material for (a) wall, (b) ceiling, (c) roof frame, and (d) roof of sago leave.

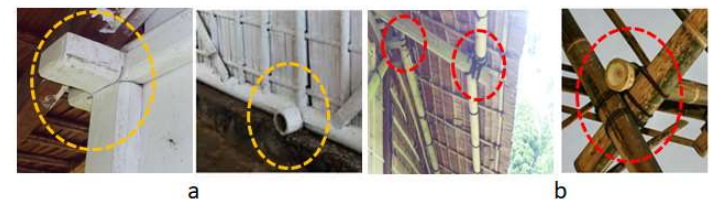

Fig. 9. Building construction: (a) Button System (b) Bond system

The Gurabunga traditional houses were built without an architect's control, but the building successfully balances environmental requirements and residential comfort by considering local culture, natural environment, indoor thermal comfort, energy consumption, and economic conditions in the past. It shows that the Gurabunga traditional architecture is very responsive to the environment and sustainability by local techniques according to the resources at that time. In addition, the Gurabunga traditional architecture has been able to withstand extreme weather conditions and natural disasters since hundreds of years ago with local construction techniques of the button and bond systems (Fig. 9) using lightweight natural materials from the surrounding environment. According to [18], people can respond to their natural characteristics with good spatial, material, and construction systems where natural factors, self, culture, and society become the circle of life in vernacular architecture.

\section{Conclusion}

Cultural values and local wisdom are very strongly in the construction process of houses and the life of the Gurabunga community. The characteristics of the Gurabunga traditional house are a traditional sacred and magical building with a philosophy of the human body anatomy in a standing position; roof (head), walls and rooms (body), foundation (foot). The space pattern is the rectangular pattern, which consists of a Konora room (living room), Jiko room (bedroom), Fuji room (ritual/magical room), Sarabi room (foyer), and a kitchen room. The Fuji room is very private and sacred in the life of the Tidore community so that the traditional house still survives to this day. The building frame uses bamboo and wood construction with a reinforcement of buttons and bond systems for natural disaster protection. Sustainable design strategies can be found in Gurabunga traditional houses with passive solar design techniques using natural materials from the surrounding environment; clay floor, bamboo walls, and roof of sago leaves. These natural materials are used to improve indoor thermal comfort and for a natural impression as a concept of "harmony with nature." The results of this study only provide an initial preview; further and detailed research is needed, especially for evaluating earthquakes resistance.

We would like to express our sincere gratitude and appreciation to the Ministry of Education, Culture, Research, and Technology, the Republic of Indonesia, for providing the research fund.

\section{References}

[1] D. Campos, I. Daniel. "Phenomenological Analysis in the Traditional Housing Architecture." International Theory and History of Architecture Conference (ARCHTHEO'17 XI), 2017.

[2] Ronald, A. Teknologi dan Arsitekur. Kekayaan dan Kelenturan Arsitektur, 1-12. Muhammadiyah University Press, Surakarta 2002.

[3] Rahmansah, B. Rauf. "Arsitektur Tradisional Bugis Makassar”. J. Forum Bangunan, 12(2) 2014.

[4] R. Scefold, P.J.M. Nas, Domenig. Indonesian Houses: Tradition and Transformation in Vernacular Architecture. Singapore University Press. 2004.

[5]. Rahmat, "Makna Simbolik Rumah Adat Folajiko Sarabi Tidore". Al-mishbah, 16(2), 223-244, 2020.

[6] J.C. Vischer. "Towards a User-centred Theory of the Built Environment". Build. Res. Inf. 36, 231240, 2008.

[7] M. Shirazi. Towards an Articulated Phenomenological Interpretation of Architecture: Phenomenal Phenomenology. Routledge: New York, NY, USA, 2013.

[8] M. Rahim, B. Hamzah. "Land Surface Effects and Thermal Performance in Hot-Humid Climate Area." International Journal of Geomate, 17 (62), 237-243, 2019.

[9] L. Balaguer. "Bioclimatic Strategies of Traditional Earthen Architecture." J. Cultural Heritage Manag. \& Sust. Dev. 9(2), 227-246 2019.

[10] S.S. Chandel, et al. "Review of Energy Efficient Features in Vernacular Architecture for Improving Indoor Thermal Comfort Conditions". Renew. \& Sust. Energy Rev. 65 459-477, 2016.

[11] P. Manurung. "Arsitektur Berkelanjutan, Belajar dari Kearifan Arsitektur Nusantara". Prosiding 
Simposium Nasional RAPI XIII. Universitas Muhammadiyah Surakarta, 75-81, 2014.

[12] Ravishankar, et al. "Influence of Culture and Tradition in the Tribal Architecture of Meghalaya." Design for Tomorrow 3. Springer, Singapore, 775-782, 2021.

[13] P. Oliver. Encyclopedia of Vernacular Architecture of the World; Cambridge University Press: Cambridge, UK, 1997.

[14] A. Rapoport. "Vernacular Architecture". Curr. Chall. Environ. Soc. Sci. 24, 30-45, 1990.

[15] L. Asquith, M. Vellinga. Vernacular Architecture in the 21st Century: Theory, Education and Practice. Taylor \& Francis: Abingdon, UK, 2006.

[16] M. Rahim, M. Ibrahim, F. Marasabessy. "Construction System and Environment Adaptation of Traditional Architecture in Moluccas Island." Civil Engineering and Architecture, 9(5), 1530-1545, 2021.

[17] Z.J. Zhai. "Review of Natural Ventilation Models". Energy Procedia, 78, 2700-2705, 2015.

[18] Solikhah et al. "Vernacular Architecture as a Representation of Nature, Self, Culture, and Society: Insights from Sumba-Timor-Flores". International Conference on Economics, Business, Social, and Humanities (ICEBSH), Atlantis Press, 2021. 